\title{
ANALISIS HUBUNGAN MOTIVASI DAN DISIPLIN KERJA KARYAWAN TERHADAP EFEKTIVITAS PELAKSANAAN MANAJEMEN MUTU PADA UNIVERSITAS BUDI LUHUR
}

\section{Dwi Kristanto}

Universitas Budi Luhur

Jl. Ciledug Raya, Petukangan Utara, Jakarta Selatan, DKI Jakarta

e-mail: dwi.kristanto@budiluhur.ac.id

\begin{abstract}
Universities as higher education institutions must be able to meet the demands of meeting high education standards to have quality education quality, in order to compete in the global world. The quality management system is expected to create higher education standards to improve the quality of education. To implement a quality management system effectively human resources are needed that have a high level of discipline and motivation. Effectiveness in implementing a quality management system requires joint commitment of all employees from top managers, middle managers and lower managers. In implementing a quality management system an interesting thing to analyze is how the relationship between motivation and the discipline of employees with the effectiveness of implementing a quality management system. This research shows that the motivation and the employee discipline are significantly affect the effectiveness of implementing a quality management system.
\end{abstract}

Keywords: motivation, discipline, employee, quality management, university

\begin{abstract}
Abstrak
Universitas sebagai lembaga pendidikan tinggi harus dapat memenuhi tututan memenuhi standar pendidikan yang tinggi untuk memiliki mutu pendidikan yang berkualitas, agar dapat bersaing di dunia global. Sistem manajemen mutu diharapkan dapat menciptakan standar pendidikan tinggi untuk meningkatkan mutu pendidikan. Untuk menerapkan sistem manajemen mutu secara efektif diperlukan sumber daya manusia yang mempunyai tingkat kedisiplinan dan motivasi yang tinggi. Efektivitas dalam menerapkan sistem manajemen mutu diperlukan komitmen bersama seluruh karyawan baik dari manajer puncak, manajer madya dan manajer bawah. Dalam menerapkan sistem manajemen mutu hal yang menarik untuk dianalisis adalah bagaimana hubungan motivasi dan disiplin kerja karyawan dengan efektivitas penerapan sistem manajemen mutu. Hasil penelitian ini menunjukkan bahwa baik secara parsial maupun bersama-sama, variabel motivasi dan disiplin kerja karyawan memiliki pengaruh yang signifikan terhadap efektivitas penerapan sistem manajemen mutu.
\end{abstract}

Kata kunci: motivasi, disiplin, karyawan, manajemen mutu, universitas

\section{PENDAHULUAN}

Lembaga pendidikan sebagai lembaga untuk mendidik para generasi muda untuk mendapatkan bekal ilmu pengetahuan memiliki cara pengelolaan yang berbeda dengan lembaga non pendidikan. Tuntutan pendidikan yang bermutu sudah harus dipenuhi, agar menghasilkan lulusan yang berkualitas yang dapat diserap di dunia kerja. Hal tersebut tentunya menjadi tantangan yang harus dapat diwujudkan untuk semua lembaga pendidikan. Manajemen pendidikan sudah saatnya untuk menciptakan manajemen pendidikan yang dikelola dengan 
administrasi yang rapi, efisien dan transparan.

Universitas Budi Luhur yang berada di bawah Yayasan Pendidikan Budi Luhur Cakti telah mengantisipasi perubahan guna menghadapi tantangan ke depan dengan meningkatkan efektivitas dan efisiensi sehingga Universitas dapat mengalokasikan sumber daya dengan mengkombinasikan antara SDM dengan strategi organisasi.

Dalam rangka Universitas Budi Luhur meningkatkan mutu pendidikan, perlu model sistem manajemen mutu yang mampu mengembangkan dan meningkatkan kualitas pendidikan serta dapat melakukan evaluasi kinerja termasuk disiplin kerja dan motivasi kerja karyawan. Sistem manajemen mutu diharapkan dapat merubah budaya kerja menjadi lebih baik yang mencakup kerja lebih sistematis, terarah dan memiliki batasbatas kewenangan yang jelas. Prosedur kerja yang baik disertai dukungan dokumentasi yang terstruktur lengkap akan menciptakan kerja menjadi lebih baik, terarah dan memberikan hasil sesuai yang diinginkan. Dengan menerapkan sistem tersebut dapat mendorong motivasi kerja dan kedisiplinan kerja karyawan dapat bekerja mencapai tujuan dan sasaran yang maksimal. Motivasi kerja dan kedisiplinan kerja sangat dibutuhkan untuk mempengaruhi kinerja setiap individu untuk menciptakan kreativitas dan inovatif.

Berdasarkan latar belakang tersebut, maka penelitian akan menitikberarkan kepada motivasi dan disiplin kerja dikaitkan serta efektivitas manajemen mutu dengan judul "Analisis hubungan motivasi dan disiplin kerja karyawan dengan efektivitas pelaksanaan manajemen mutu pada Universitas Budi Luhur. Penelitian ini bertujuan untuk menjawab permasalahan sebagai berikut:
1) Apakah terdapat hubungan yang signifikan antara motivasi kerja dengan efektivitas penerapan sistem manajemen mutu?

2) Apakah terdapat hubungan yang signifikan antara disiplin kerja dengan efektivitas penerapan sistem manajemen mutu?

3) Apakah terdapat hubungan yang signifikan antara motivasi dan disiplin kerja dengan efektivitas penerapan sistem manajemen mutu secara bersama-sama ?

\section{TINJAUAN PUSTAKA}

\section{Sumber Daya Manusia, Motivasi Kerja dan} Disiplin Kerja

Sumber daya manusia mempunyai kontribusi yang sangat penting dalam menggerakan suatau organisasi untuk menjadi effisien, effektif dan produktif. Kualitas sumber daya manusia sangat menentukan pencapaian misi dan visi perusahaan. Dalam mewujudkan sumber daya yang berkualitas, maka sangat diperlukan kepemimpinan yang efektif dan budaya organisasi yang dapat mendukung pengelolaan sumber daya manusia yang efektif dan efisien. Pada akhirnya sumber daya manusia yang benar-benar berkualitas selalu termotivasi melakukan program kerjanya secara disiplin untuk dapat melaksanakan kegiatan operasional perusahaan secara optimal.

Untuk dapat memberdayakan sumber daya manusia secara optimal di dalam suatu organisasi, perlu penetapan kebijakan dan sasaran mutu dengan menerapkan sistem manajemen mutu. Universitas menerapan sistem manajemen mutu bertujuan untuk menghasilkan pelayanan yang dapat memenuhi kepuasan pelanggan sesuai standar dan mampu bersaing dengan yang lain. Salah satu keuntungan dengan 
menerapkan sistem manajemen mutu adalah dapat meningkatkan moral dan kepercayaan karyawan dalam bekerja, karena telah melakukan pekerjaan sesuai prosedur dan kebijakan mutu standar internasional.

Pada Universitas Budi Luhur terdapat dua kategori karyawan yaitu karyawan akademik (dosen) dan karyawan nonakademik (Universitas Budi Luhur, 2011). Bagi karyawan akademik (dosen), motivasi yang ditekankan adalah motivasi dalam proses belajar mengajar siswa, motivasi untuk menggerakkan prestasi dan mengarahkan sikap siswa, menopang tingkah laku dan menyeleksi perbuatan individu yang berorientasi kepada keberhasilan siswa. Dengan demikian landasan utama adalah motivasi untuk mengarahkan berprestasi terhadap proses pembinaan, pengembangan kepribadian dan kemampuannya untuk menentukan keberhasilan seseorang.

Motivasi kerja dalam penelitian ini mencakup adanya dorongan kerja untuk bekerja baik, menerima umpan balik, mencapai tujuan dan sasaran, adanya upaya kerja untuk bertanggungjawab, berani bersaing, ketepatan menjalankan kerja sesuai metode dan adanya keinginan kerja untuk mencapai kesuksesan, menerima tugas dengan cepat, mencegah kegagalan, serta mendapat imbalan yang sesuai.

Dalam usaha meningkatkan disiplin karyawan Universitas Budi Luhur untuk menjalankan sistem manajemen mutu secara efektif, diperlukan peraturan disiplin yang memuat pokok-pokok kewajiban, larangan dan sanksi apabila kewajiban tidak ditaati atau ada larangan yang dilanggar. Dalam peraturan disiplin diatur dengan jelas kewajiban yang harus ditaati dan larangan yang tidak boleh dilanggar oleh setiap karyawan yang secara garis besarnya mengatur mengenai kataatan kerja dan perilaku karyawan. Tujuan hukuman disiplin adalah untuk memperbaiki dan mendidik karyawan yang melakukan pelanggaran disiplin dalam mengemban tugasnya. Pada penelitian ini, yang dimaksud disiplin kerja adalah ketaatan kerja yang meliputi usaha menegakan aturan, keteladanan dalam menjalankan tugas, adanya sanksi, kemangkiran yang beralasan dan perilaku karyawan yang meliputi kerja tepat waktu, berkoordinasi terhadap atasan, kreativitas dalam melaksanakan pekerjaan,dan pengembangan profesionalitas. Dari indikator-indikator disiplin tersebut diharapkan dapat mencakup untuk menjalankan penerapan sistem manajemen mutu secara efektif.

Beberapa penelitian yang mengaitkan variabel motivasi kerja dan disiplin kerja dengan kinerja karyawan maupun kualitas layanan perusahaan. Penelitian oleh South (2013) melihat pengaruh motivasi kerja dan disiplin kerja terhadap peningkatan kinerja pegawai di Kantor Kelurahan Paniki, Kecamatan Mapanget, Manado. Pada penelitian lainnya, motivasi dan disiplin kerja juga terbukti mempengaruhi kinerja karyawan di suatu perusahaan hingga 55,3\% (Mulyadi \& Marliana, 2010). Hasil sedikit berbeda ditunjukkan pada penelitian oleh (Utama, Mansur, \& Slamet, 2017) dimana motivasi kerja tidak mempengaruhi efektivitas kerja pegawai, namun disiplin kerja secara signifikan mempengaruhi kinerja pegawai. Pengaruh variabel motivasi kerja dan disiplin kerja yang cukup tinggi terhadap kinerja karyawan (sebesar 68\%) dijumpai di CV Putra Luhur Blitar (Yunimas \& Putro, 2016). Pada penelitian lainnya yang dilakukan pada PT Tambang Batubara Bukit Asam menunjukkan bahwa karakteristik individu, komunikasi dan kepuasan karyawan sangat berpengaruh terhadap kinerja 
karyawan (Agustina, Jaya, \& Pungan, 2019). Beberapa penelitian di atas menunjukkan bahwa pentingnya pengelolaan sumber daya manusia di suatu organisasi.

\section{Sistem Manajemen Mutu di Perguruan Tinggi}

Penerapan sistem manajemen mutu di lingkungan perguruan tinggi didasarkan kepada untuk dapat bersaing di masyarakat global. Rendahnya mutu pendidikan tinggi di Indonesia, faktor utama yang mendorong pengelola perguruan tinggi untuk dapat memperbaiki mutu perguruan tinggi. Mutu perguruan tinggi harus dilihat dari seluruh produknya, bukan hanya dari tingkat kemampuan lulusannya. Dengan demikian perguruan tinggi bermutu harus dipahami sebagai lembaga pendidikan tinggi yang terkelola sedemikian rupa sehingga mampu menghasilkan jasa pendidikan tinggi yang sesuai dengan kebutuhan pelanggan. Menurut Tampubolon (2001), mengenai mutu perguruan tinggi terdapat sembilan komponen yang perlu distandarisasikan, yang meliputi : jasa kurikuler, jasa penelitian, jasa pengabdian pada masyarakat, jasa administrasi, jasa ekstrakurikuler, lulusan, sumber daya manusia, sarana / prasarana dan pelanggan primer. Sedangkan yang dimaksud dengan mutu perguruan tinggi adalah kesesuaian sifat-sifat produk perguruan tinggi dengan kebutuhan pelanggan, terutama mahasiswa sebagai pelanggan primer, dan dunia kerja sebagai pelanggan tersier.

Konsep mutu yang mengisyaratkan perlu diterapkannya dalam manajemen perguruan tinggi, merupakan paradigma baru dalam manajemen perguruan tinggi di Indonesia. Paradigma lama yang pada umumnya masih dianut di perguruan tinggi, mengaitkan mutu dengan jumlah lulusan dan kemampuan akademik yang dicapai. Apabila persentase lulusan tinggi dan rata-rata indeks prestasinya kumulatif tinggi, maka perguruan tinggi itu disebut bermutu.

Atribut-atribut mutu perguruan tinggi dalam paradigma baru mencakup sebelas hal, meliputi :

1) Relevansi : kesesuaian dengan kebutuhan.

2) Efisiensi : kehematan dalam penggunaan sumber daya ( dana, tenaga, waktu, dan lain-lain) untuk produksi dan penyajian jasa-jasa perguruan tinggi yang sesuai dengan kebutuhan pelanggan.

3) Efektivitas : kesesuaian perencanaan dengan hasil yang dicapai, atau ketepatan sistem, metode, dan atau proses (prosedur) yang dipergunakan untuk menghasilkan jasa yang direncanakan.

4) Akuntabilitas (kebertanggungjawaban) : dapat tidaknya kinerja dan produk perguruan tinggi, termasuk perilaku para pengelola, dipertanggungjawabkan secara hukum, etika, akademik, agama, dan nilai budaya.

5) Kreativitas : kemampuan perguruan tinggi untuk mengadakan inovasi, pembaharuan, atau menciptakan sesuatu yang sesuai dengan perkembangan zaman, termasuk kemampuan evaluasi diri.

6) Situasi menang-menang : suasana yang menyenangkan dan memotivasi dalam perguruan tinggi sehingga semua orang melaksanakan tugasnya dengan senang hati, tulus dan penuh semangat.

7) Penampilan (tangibility) : kerapian, kebersihan, keindahan, dan keharmonisan fisik perguruan tinggi, terutama para pengelola ( pimpinan, dosen, pegawai administrasi ) yang membuat situasi dan pelayanan semakin menarik. 
8) Empati ; kemampuan perguruan tinggi, khususnya para pengelola, memberikan pelayanan sepenuh dan setulus hati kepada semua pelanggannya.

9) Ketanggapan (responsiveness) : kemampuan perguruan tinggi, khususnya para pengelola, dalam memperhatikan dan memberikan respon terhadap keadaan serta kebutuhan pelanggan dengan cepat dan tepat.

10) Produktivitas : kemampuan perguruan tinggi dan seluruh staf pengelola untuk menghasilkan produk yang sesuai dengan kebutuhan pelanggan menurut rencana yang telah ditetapkan, baik secara kuantitatif maupun kualitatif.

11) Kemampuan akademik : penguasaan mahasiswa atas bidang studi yang diambilnya. Dengan kata lain, apabila berbicara tentang mutu perguruan tinggi, yang dimaksud adalah mutu terpadu dari berbagai atribut mutu perguruan tinggi tersebut.

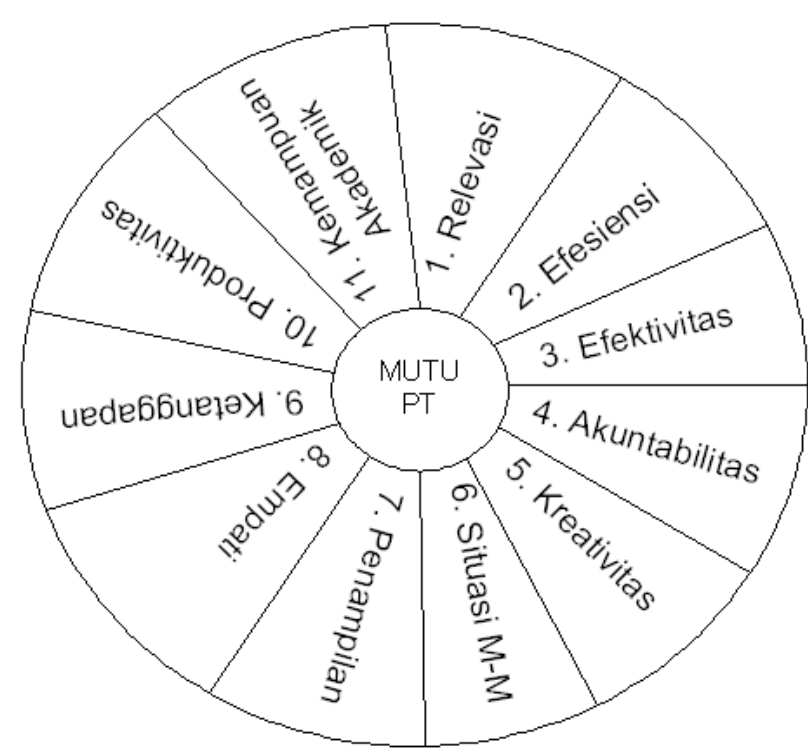

Gambar 1. Diagram Mutu Perguruan Tinggi dan Atribut-atributnya (Tampubolon, 2001)

Salah satu cara untuk dapat meningkatkan mutu yang dikelola dengan berlandaskan atribut-atribut mutu dalam perguruan tinggi adalah dengan penerapan sistem manajemen mutu ISO 9001:2008. Efektivitas dalam penerapan sistem manajemen mutu mencakup kebijakan organisasi yang meliputi tanggung jawab dan kewenangan, tujuan, dan target yang akan dicapai. Indikator tersebut akan menghasilkan sumber daya manusia yang selalu mengutamakan kualitas produknya (jasa). Kualitas meliputi kebijakan mutu, perencanaan mutu, dan sistem mutu. Indikator tersebut merupakan proses - proses yang harus dilakukan untuk menghasilkan kualitas produk (jasa). Dan budaya kerja yang meliputi cara kerja mudah dimengerti, kerja tapat waktu, keterlibatan tugas jelas, efisien dan efektifitas kerja, sesuai kondisi kerja, mengarah lebih baik dan jelas, tersosialisasi. Indikator tersebut sebagai ukuran untuk dapat mengetahui efektivitas atau tidak di dalam penerapan sistem manajemen mutu berbasis ISO.

\section{METODE PENELITIAN}

\section{Metode Penelitian}

Penelitian ini bertujuan untuk mengetahui tingkat pengaruh motivasi dan disiplin kerja dengan efektivitas penerapanan sistem manajemen Mutu berbasis ISO 9001:2008 terhadap karyawan, baik secara sendiri-sendiri maupun secara bersama-sama. Penelitian ini merupakan penelitian kausal asosiatif-survey, yaitu penelitian yang bertujuan untuk mengetahui hubungan sebab akibat antara variabel independen (motivasi dan disiplin kerja) dengan variabel dependen (efektivitas penerapan sistem manajemen mutu).

Dalam penelitian ini variable-variabel yang digunakan adalah sebagai berikut :

1) Variabel bebas (independen), adalah variabel-variabel yang mempengaruhi 
variabel lain. Dalam hal ini yang menjadi variabel bebas adalah motivasi kerja $\left(\mathrm{X}_{1}\right)$ dan disiplin kerja karyawan $\left(\mathrm{X}_{2}\right)$.

2) Variabel terikat (dependen), adalah variabel-variabel yang dipengaruhi variabel lainnya. Dalam hal ini yang menjadi variabel terikat adalah efektivitas penerapan sistem manajemen mutu (Y)

Hubungan ketiga variabel tersebut dapat dilihat pada Gambar 2

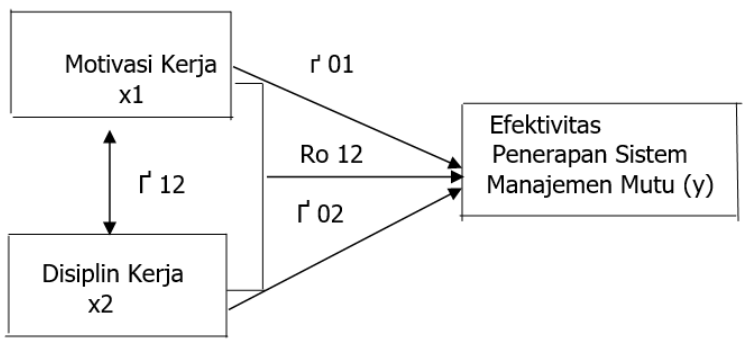

Gambar 2. Bentuk hubungan antara variabel bebas dengan variabel terikat
Bentuk kuesioner pengukuran motivasi kerja $\left(\mathrm{X}_{1}\right)$, disiplin kerja $\left(\mathrm{X}_{2}\right)$ dan efektivitas penerapan sistem manajemen mutu (Y) adalah tipe pilihan yang menggunakan skala Likert sebanyak 5 tingkat. Adapun langkah-langkah dalam penyusunan kuesioner dijabarkan dalam bentuk-bentuk kisi-kisi instrumen penelitian (Tabel 1).

\section{Data Penelitian}

Di dalam penelitian ini, pengumpulan data diambil dari data primer dan sekunder. Data primer diperoleh melalui penyebaran kuesioner dan wawancara langsung kepada responden. Data sekunder diperoleh melalui penyelusuran hasil-hasil penelitian yang telah dilakukan oleh penelitian lain, dan informasi lain yang diambil dari studi pustaka dan dokumen yang relevan dengan penelitian ini.

Tabel 1. Rancangan indikator dan pertanyaan kuesioner penelitian

\begin{tabular}{|c|c|c|c|}
\hline Variabel & Dimensi & Indikator & Item Pertanyaan \\
\hline \multirow{3}{*}{ Motivasi Kerja } & 1. Dorongan Kerja & $\begin{array}{l}\text { - Bekerja baik } \\
\text { - Umpan balik } \\
\text { - Mencapai tujuan dan sasaran }\end{array}$ & $\begin{array}{l}1,2 \\
3,4 \\
5,6\end{array}$ \\
\hline & 2. Upaya Kerja & $\begin{array}{l}\text { - Bertanggung jawab } \\
\text { - Berani bersaing } \\
\text { - Ketepatan menjalankan kerja sesuai metode }\end{array}$ & $\begin{array}{l}7,8 \\
9,10 \\
11,12 \\
\end{array}$ \\
\hline & 3. Keinginan Kerja & $\begin{array}{l}\text { - Mencapai kesuksesan } \\
\text { - Menerima tugas dengan cepat } \\
\text { - Mencegah kegagalan } \\
\text { - Mendapat imbalan yang sesuai }\end{array}$ & $\begin{array}{l}13,14,15 \\
16,17 \\
18,19,20 \\
21,22\end{array}$ \\
\hline \multirow{2}{*}{ Disiplin Kerja } & 1.Ketaatan Kerja & $\begin{array}{l}\text { - Usaha menegakan aturan } \\
\text { - Keteladanan dalam menjalankan tugas } \\
\text { - Adanya sanksi } \\
\text { - Kemangkiran yang beralasan } \\
\text { - Pengawasan }\end{array}$ & $\begin{array}{l}1,2,3 \\
4,5,6 \\
7,8 \\
9,10,11 \\
12,13\end{array}$ \\
\hline & 2. Perilaku Karyawan & $\begin{array}{l}\text { - Tepat waktu } \\
\text { - Berkoordinasi terhadap atasan } \\
\text { - Kreativitas dalam melaksanakan pekerjaan } \\
\text { - Pengembangan Profesionalitas }\end{array}$ & $\begin{array}{l}14,15 \\
16,17,18 \\
19,20 \\
21,22,23\end{array}$ \\
\hline Efektivitas & 1.Kebijakan Organisasi & $\begin{array}{l}\text { - Tanggung jawab dan kewenangan } \\
\text { - Tujuan } \\
\text { - Target yang akan dicapai } \\
\text { - Kebijakan mutu } \\
\text { - Perencanaan mutu } \\
\text { - Sistem mutu }\end{array}$ & $\begin{array}{l}1,2 \\
3,4 \\
5,6 \\
7,8 \\
9,10 \\
11,12\end{array}$ \\
\hline
\end{tabular}




\begin{tabular}{|c|c|c|c|}
\hline \multirow{2}{*}{$\begin{array}{l}\text { Penerapan } \\
\text { Sistem } \\
\text { Manajemen } \\
\text { Mutu ISO } \\
\text { 9001:2008 }\end{array}$} & 2. Kualitas & $\begin{array}{l}\text { - Cara kerja mudah dimengerti, dilaksanakan } \\
\text { - Kerja tepat waktu } \\
\text { - Keterlibatan tugas jelas }\end{array}$ & $\begin{array}{l}13,14 \\
15,16 \\
17,18\end{array}$ \\
\hline & 3. Budaya Kerja & $\begin{array}{l}\text { - Effisien dan efektifitas kerja } \\
\text { - Disesuaikan kondisi kerja yang ada } \\
\text { - Mengarah lebih baik dan jelas } \\
\text { - Tersosialisasi }\end{array}$ & $\begin{array}{l}19,20 \\
21,22 \\
23,24 \\
25\end{array}$ \\
\hline
\end{tabular}

Populasi dalam penelitian ini adalah semua karyawan Universitas Budi Luhur. Sampel atau responden dipilih berdasarkan posisi atau jabatan di Universitas Budi Luhur. Pengambilan sampel dilakukan dengan metode pengambilan sampel secara proporsional menurut unit kerja (Sekaran, 2011). Setiap individu dalam populasi setiap unit kerja diberikan kesempatan yang sama untuk dipilih menjadi responden. Dengan jumlah populasi sebanyak 240 orang, sample yang diambil sebanyak 48 orang, yaitu $20 \%$ dari jumlah populasi keseluruhan.

\section{HASIL DAN PEMBAHASAN}

Penelitian ini melibatkan tiga variabel, yaitu motivasi kerja $\left(\mathrm{X}_{1}\right)$ dan disiplin kerja $\left(\mathrm{X}_{2}\right)$ sebagai variabel independen, dan efektivitas penerapan sistem manajemen mutu (Y) sebagai variabel dependen. Dalam penelitian jumlah sample 48 responden, deskripsi dari tiap-tiap variable adalah sebagai berikut:

\section{Variabel Motivasi Kerja (X1)}

1. Statistik Deskriptif

Tabel 2. Sebaran Nilai Responden terhadap variabel Motivasi Kerja

\begin{tabular}{|c|c|c|c|}
\hline \multirow{2}{*}{$\begin{array}{c}\text { Interval } \\
\text { Kelas }\end{array}$} & \multirow{2}{*}{$\begin{array}{c}\text { Frekuensi } \\
\text { ( f1) }\end{array}$} & \multicolumn{2}{|c|}{ Frekuensi } \\
\cline { 3 - 4 } & & Kumulatif & Relatif \\
\hline $66-68$ & 2 & 2 & 4,17 \\
\hline $69-71$ & 4 & 6 & 8,33 \\
\hline $72-74$ & 8 & 14 & 16,66 \\
\hline $75-77$ & 13 & 27 & 27,1 \\
\hline $78-80$ & 14 & 41 & 29,16 \\
\hline $81-83$ & 4 & 45 & 8,33 \\
\hline
\end{tabular}

\begin{tabular}{|l|c|c|c|}
\hline $84-86$ & 3 & 48 & 6,25 \\
\hline Jumlah & 48 & & 100 \\
\hline \multicolumn{4}{|c|}{ Berdasarkan data yang telah }
\end{tabular}
dikumpulkan tentang variabel motivasi kerja diperoleh 48 responden yang valid. Sebaran nilai responden terhadap variabel motivasi kerja dapat dilihat pada Tabel 2. Berdasarkan penilaian dari responden, diperoleh beberapa data statistik antara lain rentang nilai responden antara 66 dan 85 dalam skala 100, nilai rata-rata sebesar 76,41 , persentase nilai di bawah rata-rata sebesar $29,16 \%$, di daerah rata-rata sebesar $27,08 \%$ dan di atas rata-rata sebesar $43,75 \%$.

\section{Uji Hipotesis}

Pengujian hipotesis dilakukan dengan menggunakan uji dua pihak (two tail test) dengan tingkat kepercayaan (signifikansi) sebesar $95 \%$ atau $\alpha=0,05$ dibagi 2, sehingga posisi kiri dan posisi kanan masingmasing alpha sebesar 0,025. Dengan menetapkan derajat kebebasan atau degree of freedom (df), maka indeks $\mathrm{t}$ tabel yaitu sebesar 2,021. Hasil perhitungan dengan bantuan SPSS versi 10.0 diperoleh hasil $t$ hitung sebesar 3,533. Hasil Output SPSS nilai koefisien regresi motivasi dengan efektivitas penerapan sistem manajemen mutu. Oleh karena t hitung $(3,533)>$ dari $t$ tabel (2,021), maka Ho1 ditolak, artinya terdapat korelasi yang signifikan antara motivasi kerja dengan efektivitas penerapan sistem manajemen mutu.

\section{Uji Regresi}


Perhitungan regresi sederhana digunakan rumus $\mathrm{Y}=\mathrm{a}+\mathrm{bX}$. Dengan menggunakan pengolahan data program SPSS 10.0 diperoleh hasil pada Tabel 3.

Berdasarkan perhitungan regresi pada Tabel 3, diperoleh hasil persamaan regresi $Y$ $=39,826+0,439 X 1$. Hasil perhitungan persamaan regresi sederhana menunjukkan bahwa $\mathrm{X}_{1}$ (variabel independen motivasi kerja) menghasilkan angka koefisien regresi positif sebesar 0,439 terhadap variabel dependen efektivitas penerapan sistem manajemen mutu (Y). Persamaan regresi tersebut menunjukkan bahwa kenaikan 1 (satu) unit motivasi kerja akan diikuti kenaikkan 0,439 unit efektivitas penerapan sistem manajemen mutu (lihat Gambar 3).

Tabel 3. Hasil Analisis Anova Variabel Motivasi Kerja

\begin{tabular}{|c|c|r|r|r|c|}
\hline Model & $\begin{array}{c}\text { Sum of } \\
\text { Squares }\end{array}$ & Df & $\begin{array}{c}\text { Mean } \\
\text { Square }\end{array}$ & F & Sig \\
\hline $\begin{array}{c}\text { 1 } \\
\text { Regression } \\
\text { Residual }\end{array}$ & 182.047 & 1 & 182.047 & 12.481 & .001 \\
& 670.932 & 46 & 14.585 & & \\
Total & 852.979 & 47 & & & \\
a. Predictors: (Constant), Motivasi Kerja \\
b. Dependent Variable: Efektivitas Penerapan \\
Sistem Manajemen Mutu
\end{tabular}

Coefficients

\begin{tabular}{|c|c|c|c|c|c|}
\hline \multirow{2}{*}{ Model } & \multicolumn{2}{|c|}{$\begin{array}{c}\text { Unstandardized } \\
\text { Coefficients }\end{array}$} & \multirow{2}{*}{$\begin{array}{c}\begin{array}{c}\text { Standardized } \\
\text { Coefficients }\end{array} \\
\text { Beta }\end{array}$} & \multirow{2}{*}{ t } & \multirow{2}{*}{ Sig } \\
\hline & B & $\begin{array}{l}\text { Std. } \\
\text { Error }\end{array}$ & & & \\
\hline $\begin{array}{l}\text { Constant } \\
\text { Motivasi }\end{array}$ & 39.826 & 9.506 & & 4.189 & .000 \\
\hline Kerja & .439 & .124 & .462 & 3.533 & .001 \\
\hline
\end{tabular}

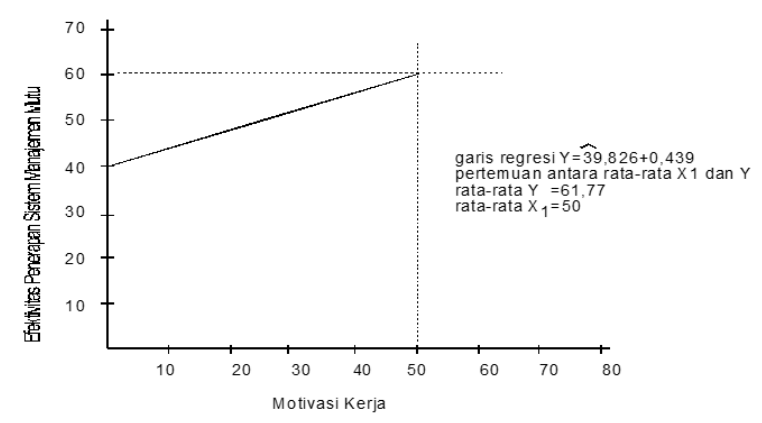

Gambar 3. Garis regresi variabel motivasi kerja terhadap efektivitas penerapan manajemen mutu
4. Uji Determinasi

Jika dilihat kekuatan hubungan antara motivasi kerja $\left(\mathrm{X}_{1}\right)$ dengan efektivitas penerapan sistem manajemen mutu (Y) berdasarkan kriteria dari Guilford (Gujarati, 2004), koefisien korelasi sedang. Dengan mengkuadratkan korelasi dapat diketahui kekuatan hubungannya yakni sebesar $(0,462)^{2}=0,213$ (R Square) dikalikan 100\% berarti $21,3 \%$. Hal tersebut berarti variabel dependen (efektivitas penerapan sistem manajemen mutu ) dapat diprediksi sebesar $21,3 \%$ oleh variabel independen motivasi kerja. Dengan kata lain efektivitas penerapan sistem manajemen mutu yang dicapai sebesar $21,3 \%$ adalah karena variabel motivasi kerja. Sedangkan sisanya sebesar 78,7 \% adalah pengaruh variabel lain yang tidak diteliti dalam penelitian ini.

\section{Disiplin Kerja $\left(X_{2}\right)$}

1. Statistik Deskriptif Variabel Disiplin $\operatorname{Kerja}\left(\mathrm{X}_{2}\right)$

Berdasarkan data yang telah dikumpulkan tentang variabel disiplin kerja diperoleh 48 responden yang valid. Sebaran nilai responden terhadap variabel disiplin kerja dapat dilihat pada Tabel 4. Berdasarkan penilaian dari responden, diperoleh beberapa data statistik antara lain rentang nilai responden antara 64 dan 80 dalam skala 100, nilai rata-rata sebesar 70,27 , persentase nilai di bawah rata-rata sebesar $43,75 \%$, di daerah rata-rata sebesar $25 \%$ dan di atas rata-rata sebesar $31,25 \%$.

Tabel 4. Sebaran nilai responden terhadap variabel disiplin kerja

\begin{tabular}{|c|c|c|c|}
\hline \multirow{2}{*}{$\begin{array}{c}\text { Interval } \\
\text { Kelas }\end{array}$} & \multirow{2}{*}{$\begin{array}{c}\text { Frekuensi ( } \\
\text { f1) }\end{array}$} & \multicolumn{2}{|c|}{ Frekuensi } \\
\cline { 3 - 4 } & & Kumulatif & Relatif \\
\hline $64-66$ & 11 & 11 & 22,92 \\
\hline $67-69$ & 10 & 21 & 20,83 \\
\hline $70-72$ & 12 & 33 & 25 \\
\hline $73-75$ & 9 & 42 & 18,75 \\
\hline $76-78$ & 3 & 45 & 6,25 \\
\hline
\end{tabular}




\begin{tabular}{|c|c|c|c|}
\hline $79-81$ & 3 & 48 & 6,25 \\
\hline Jumlah & 48 & & 100 \\
\hline
\end{tabular}

\section{Uji Hipotesis}

Pengujian hipotesis dilakukan dengan menggunakan uji dua pihak (two tail test) dengan tingkat kepercayaan (signifikansi) sebesar $95 \%$ atau $\alpha=0,05$ dibagi 2, sehingga posisi kiri dan posisi kanan masing-masing alpha sebesar 0,025. Dengan menetapkan derajat kebebasan atau degree of freedom (df), maka indeks t tabel yaitu sebesar 2,021. Hasil perhitungan dengan bantuan SPSS versi 10.0 diperoleh hasil t hitung sebesar 3,178. Hasil Output SPSS nilai koefisien regresi disiplin kerja dengan efektivitas penerapan sistem manajemen mutu. Oleh karena t hitung $(3,178)>$ dari t tabel $(2,021)$, maka Ho1 ditolak, artinya terdapat korelasi yang signifikan antara disiplin kerja dengan efektivitas penerapan sistem manajemen mutu.

\section{Uji Regresi}

Perhitungan regresi sederhana menggunakan persamaan $\mathrm{Y}=\mathrm{a}+\mathrm{bX}_{2}$. Dengan menggunakan pengolahan data program SPSS 10.0 diperoleh hasil seperti ditampilkan pada Tabel 5.

\section{Tabel 5. Hasil analisis Anova terhadap Variabel Disiplin Kerja (X2)}

\begin{tabular}{|c|r|r|r|c|c|}
\hline Model & $\begin{array}{c}\text { Sum of } \\
\text { Squares }\end{array}$ & Df & $\begin{array}{c}\text { Mean } \\
\text { Square }\end{array}$ & F & Sig \\
\hline Regression & 153.564 & 1 & 153.564 & 10.100 & .003 \\
Residual & 699.415 & 46 & 15.205 & & \\
Total & 852.979 & 47 & & & \\
\hline
\end{tabular}

a. Predictors: (Constant), Disiplin Kerja

b. Dependent Variable: Efektivitas Penerapan Sistem Manajemen Mutu

\begin{tabular}{|c|c|c|c|c|c|}
\multicolumn{7}{c|}{ Coefficients } \\
\hline \multirow{3}{*}{ Model } & \multicolumn{2}{|c|}{$\begin{array}{c}\text { Unstandardized } \\
\text { Coefficients }\end{array}$} & $\begin{array}{c}\text { Standardized } \\
\text { Coefficients }\end{array}$ & \multirow{2}{*}{ t } & \multirow{2}{*}{ Sig } \\
\cline { 2 - 4 } & B & $\begin{array}{c}\text { Std. } \\
\text { Error }\end{array}$ & Beta & & \\
\hline Constant & 44.761 & 9.015 & & 4.965 & .000 \\
\hline
\end{tabular}

\begin{tabular}{|l|l|l|l|l|l|}
\hline $\begin{array}{l}\text { Disiplin } \\
\text { Kerja }\end{array}$ & .407 & .128 & .424 & 3.178 & .003 \\
\hline
\end{tabular}

a. Dependent Variabel : Efektivitas Penerapan Sistem Manajemen Mutu

Berdasarkan perhitungan regresi dengan metode tersebut diatas diperoleh persamaan regresi $\mathrm{Y}=44,761+0,407 \mathrm{X}_{2}$. Hasil perhitungan persamaan regresi sederhana menunjukkan bahwa $\mathrm{X}_{2}$ yang merupakan variabel independen disiplin kerja menghasilkan angka koefisien regresi positif sebesar 0,407 terhadap variabel dependen efektivitas penerapan sistem manajemen mutu. Persamaan regresi tersebut menunjukkan bahwa kenaikan 1 unit disiplin kerja akan diikuti kenaikkan 0,407 unit efektivitas penerapan sistem manajemen mutu.

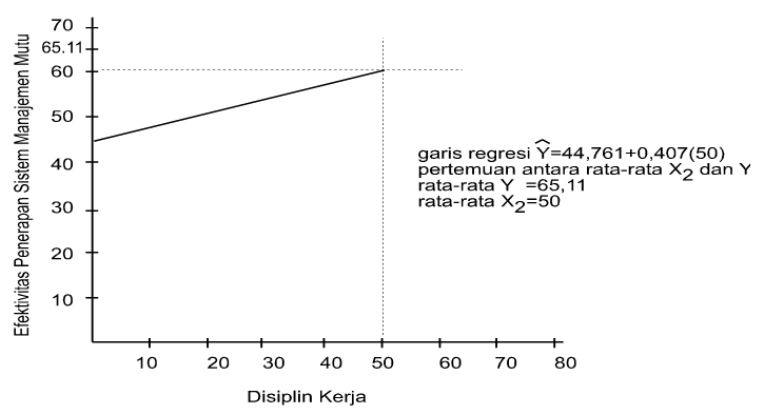

Gambar 4. Garis Regresi Nilai Disiplin Kerja dan Nilai rata-rata

\section{Uji Determinasi}

Jika dilihat kekuatan hubungan antara disiplin kerja $\left(\mathrm{X}_{2}\right)$ dengan efektivitas penerapan sistem manajemen mutu (Y) berdasarkan kriteria dari Guilford (Gujarati, 2004), koefisien korelasi sedang. Dengan mengkuadratkan korelasi dapat diketahui kekuatan hubungannya yakni sebesar $(0,424)^{2}=0,180$ (R Square) dikalikan 100\% berarti $18 \%$. Ini berarti variabel dependen (efektivitas penerapan sistem manajemen mutu) dapat diprediksi sebesar $18 \%$ oleh variabel independen disiplin kerja. Dengan kata lain, efektivitas penerapan sistem manajemen mutu yang dicapai sebesar $18 \%$ 
adalah karena variabel disiplin kerja. Sedangkan sisanya sebesar $82 \%$ adalah pengaruh variable lain yang tidak diteliti dalam penelitian ini.

\section{Efektivitas Penerapan Sistem Manajemen Mutu}

1. Statistik Deskriptif Variabel Efektivitas Sistem Manajemen Mutu (Y)

Berdasarkan data yang telah dikumpulkan tentang variabel efektivitas penerapan sistem manajemen mutu (SMM) diperoleh 48 responden yang valid. Sebaran nilai responden terhadap variabel efektivitas SMM dapat dilihat pada Tabel 6 . Berdasarkan penilaian dari responden, diperoleh beberapa data statistik antara lain rentang nilai responden antara 65 dan 83 dalam skala 100, nilai rata-rata sebesar 73,35, persentase nilai di bawah rata-rata sebesar $56,25 \%$, di daerah rata-rata sebesar $22,91 \%$ dan di atas rata-rata sebesar $20,83 \%$.

Tabel 6. Sebaran nilai responden terhadap variabel Efektivitas Penerapan SMM

\begin{tabular}{|c|c|c|c|}
\hline Interval & Frekuensi & \multicolumn{2}{|c|}{ Frekuensi } \\
\cline { 3 - 4 } Kelas & (f1) & Kumulatif & Relatif \\
\hline $65-67$ & 4 & 4 & 8,33 \\
\hline $68-70$ & 8 & 12 & 16,66 \\
\hline $71-73$ & 15 & 27 & 31,25 \\
\hline $74-76$ & 11 & 38 & 22,92 \\
\hline $77-79$ & 5 & 43 & 10,42 \\
\hline $80-82$ & 4 & 47 & 8,33 \\
\hline $83-85$ & 1 & 48 & 2,09 \\
\hline Jumlah & 48 & & 100 \\
\hline
\end{tabular}

\section{Uji Korelasi}

Berdasarkan data yang terkumpul untuk setiap variabel dan setelah dihitung korelasi sederhananya sebagai berikut :

1) Korelasi antara motivasi kerja dengan efektivitas penerapan sistem manajemen mutu adalah sebesar $r_{\mathrm{yx} 1}=0,462$
2) Korelasi antara disiplin kerja dengan efektivitas penerapan sistem manajemen mutu adalah sebesar $r_{\mathrm{yx} 2}=0,424$

3) Korelasi antara sesama variabel kriterium, motivasi kerja dengan disiplin kerja adalah sebesar $r_{x 1 \times 2}=0,436$

Berdasarkan data tersebut maka koefisien ganda antara motivasi kerja $\left(\mathrm{X}_{1}\right)$ dan disiplin kerja $\left(\mathrm{X}_{2}\right)$ secara bersama-sama dengan efektivitas penerapan sistem manajemen mutu (Y) dapat dihitung dengan persamaan :

$$
R_{y \cdot x_{1} x_{2}}=\sqrt{\frac{r_{y x_{1}}^{2}+r^{2} x_{2}-2 r_{y x_{1}} r_{y_{2}} r_{x_{1} x_{2}}}{1-r^{2} x_{1} x_{2}}}
$$

Dengan bantuan program SPSS versi 10.0 diperoleh hasil $\mathrm{R}$ sebesar seperti dalam Tabel 7. Dengan demikian, dapat diketahui hasil koefisien ganda antara variabel motivasi kerja dan variabel disiplin kerja secara bersama-sama dengan efektivitas penerapan sistem manajemen mutu adalah sebesar 0,524 .

Tabel 7. Hasil Output Koefisien Ganda Model Summary

\begin{tabular}{|l|c|r|r|c|}
\hline Model & $\mathbf{R}$ & $\begin{array}{c}\mathbf{R} \\
\text { Square }\end{array}$ & $\begin{array}{c}\text { Adjusted } \\
\mathbf{R} \\
\text { Square }\end{array}$ & $\begin{array}{c}\text { Std.Error } \\
\text { of } \\
\text { The } \\
\text { Estimate }\end{array}$ \\
\hline 1 & $.524^{\mathrm{a}}$ & .275 & .242 & 3.7078 \\
\hline
\end{tabular}

a. Predictors: (Constant), Motivasi Kerja, Disiplin kerja

\section{Uji Hipotesis}

Pengujian hipotesis dilakukan dengan menggunakan uji satu pihak (one tail test) dengan tingkat kepercayaan (signifikansi) 95 $\%$ atau $\alpha=0,05$, maka diketahui $\mathrm{F}$ tabel $\mathrm{F}$ $0,05(45,2)$ sebesar 3,2. Kriteria Pengujian $=>$ Tolak Ho, jika $\mathrm{F}$ hitung $>\mathrm{F}$ tabel

Data yang digunakan adalah nilai distribusi $\mathrm{F}$ yang diperoleh berdasarkan hasil pengolahan data SPSS 10.0 diperoleh nilai 
sebesar 8,522, sedangkan dengan cara penghitungan diperoleh $\mathrm{F}$ hitung sebesar 3,2. Gambar 5 menampilkan grafik uji hipotesis antara variabel $\mathrm{X}_{1}$ dan $\mathrm{X}_{2}$ secara bersamasama terhadap variabel $Y$. Dari hasil perhitungan, terlihat bahwa nilai 8,522 $>3,2$, maka Ho ditolak, artinya terdapat korelasi yang signifikan secara bersama-sama antara motivasi kerja dan disiplin kerja dengan efektivitas penerapan sistem manajemen mutu.

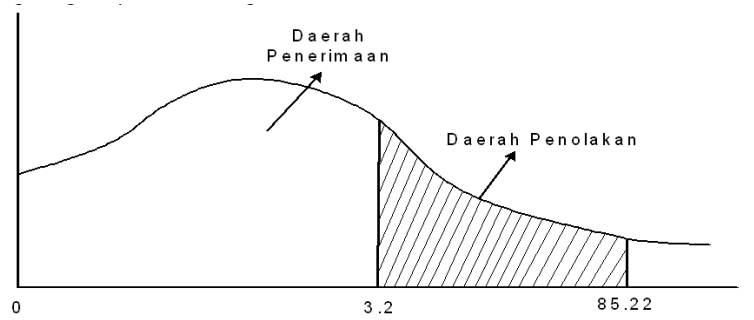

Gambar 5. Grafik Uji Hipotesis antara variabel $\mathrm{X} 1, \mathrm{X} 2$ secara bersama-sama terhadap variabel $\mathrm{Y}$

\section{Uji Regresi Ganda}

Perhitungan regresi ganda menggunakan persamaan $\mathrm{Y}=\mathrm{a}+\mathrm{b}_{1} \mathrm{X}_{1}+$ $\mathrm{b}_{2} \mathrm{X}_{2}$ (Sugiyono, 2012; Sujarweni, 2012). Dengan menggunakan pengolahan data program SPSS 10.0 diperoleh hasil seperti pada Tabel 8. Berdasarkan perhitungan regresi berganda diperoleh hasil persamaan $\mathrm{Y}$ $=29,997+0,325 \mathrm{X}_{1}+0,264 \mathrm{X}_{2}$.

Tabel 8. Hasil analisis regresi ganda variabel X1, X2 terhadap $\mathrm{Y}$

\begin{tabular}{|r|r|r|r|c|c|}
\hline \multicolumn{1}{|c|}{ Model } & $\begin{array}{c}\text { Sum of } \\
\text { Squares }\end{array}$ & df & $\begin{array}{c}\text { Mean } \\
\text { Square }\end{array}$ & F & Sig \\
\hline Regression & 234.320 & 2 & 117.160 & 8.522 & .001 \\
Residual & 618.659 & 45 & 13.748 & & \\
Total & 852.979 & 47 & & & \\
\hline
\end{tabular}

a. Predictors: (Constant), Motivasi Kerja, Disiplin Kerja

b. Dependent Variable: Efektivitas Penerapan Sistem Manajemen Mutu

\begin{tabular}{|c|c|c|c|c|c|}
\hline \multicolumn{6}{|c|}{ Coefficients } \\
\hline \multirow{2}{*}{ Model } & \multicolumn{2}{|c|}{$\begin{array}{c}\text { Unstandardized } \\
\text { Coefficients }\end{array}$} & \multirow{2}{*}{\begin{tabular}{|c}
$\begin{array}{c}\text { Standardized } \\
\text { Coefficients }\end{array}$ \\
Beta
\end{tabular}} & \multirow{2}{*}{$\mathbf{t}$} & \multirow{2}{*}{ Sig } \\
\hline & B & $\begin{array}{c}\text { Std. } \\
\text { Error }\end{array}$ & & & \\
\hline \begin{tabular}{|l} 
(Constant) \\
\end{tabular} & 29.997 & 10.516 & & 2.852 & .007 \\
\hline
\end{tabular}

\begin{tabular}{|l|r|r|r|r|r|}
\hline Motivasi Kerja & .325 & .134 & .342 & 2.424 & .019 \\
Disiplin Kerja & .264 & .135 & .275 & 1.950 & .045 \\
\hline
\end{tabular}

a. Dependent Variabel : Efektivitas Penerapan Sistem Manajemen Mutu

Hasil perhitungan regresi berganda tersebut menunjukkan bahwa variabel independen motivasi kerja menghasilkan angka koefisien regresi positif sebesar 0,325 sedangkan variabel independen disiplin kerja menghasilkan angka koefisien regresi positif sebesar 0,264 terhadap variabel dependen efektivitas penerapan sistem manajemen mutu. Persamaan regresi tersebut menunjukkan bahwa jika motivasi dan disiplin kerja secara bersama-sama ditingkatkan 1 (satu) unit, maka akan berpengaruh terhadap meningkatnya efektivitas penerapan sistem manajemen mutu sebesar 0, 325 dan 0,264.

\section{Uji Determinasi}

Jika dilihat kekuatan hubungan antara motivasi kerja $\left(\mathrm{X}_{1}\right)$ dan disiplin kerja $\left(\mathrm{X}_{2}\right)$ secara bersama-sama dengan efektivitas penerapan sistem manajemen mutu (Y) berdasarkan kriteria dari Guilford (Gujarati, 2004), koefisien korelasi sedang. Dengan mengkuadratkan korelasi dapat diketahui kekuatan hubungannya yakni sebesar $(0,524)^{2}=0,275$ (R Square) dikalikan 100\% berarti $27,5 \%$. Ini berarti variabel dependen (efektivitas penerapan sistem manajemen mutu) dapat diprediksi sebesar $27,5 \%$ oleh variabel independen motivasi kerja dan disiplin kerja secara bersama-sama.

\section{Pembahasan}

Analisis korelasi terhadap variabel motivasi kerja dengan variabel efektivitas penerapan sistem manajemen mutu diperoleh hasil koefisien korelatif 0,462 (t-hitung) dan nilai koefisien determenasi sebesar $21,3 \%$. 
Nilai koefisien korelasi yang diperoleh dibandingkan dengan nilai t-tabel $=0,288$ dengan sampel data 48 dan taraf signifikan $5 \%$. Terlihat bahwa nilai t-hitung lebih besar t-tabel atau 0,462 > 0,288, maka dapat dinyatakan terdapat hubungan yang positif dan signifikan antara motivasi kerja dengan efektivitas penerapan sistem manajemen mutu pada Universitas Budi Luhur. Hubungan motivasi dengan efektivitas penerapan sistem manajemen mutu dapat diketahui melalui nilai koefisien determinasi $\mathrm{r}^{2}=(0,462)^{2}=0,213$. Jadi varian yang terjadi pada motivasi sebesar $21,3 \%$ dapat dijelaskan melalui varian yang terjadi pada efektivitas penerapan sistem manajemen mutu, sedangkan sisanya sebesar 78,7\% disebabkan oleh faktor lain. Model persamaan regresi linier sederhana yang diperoleh $\mathrm{y}=39,826+0,439 \mathrm{X}_{1}$.

Analisis korelasi terhadap variabel disiplin kerja dengan variabel efektivitas penerapan sistem manajemen mutu diperoleh hasil koefisien korelatif 0,424 (t-hitung ) dan nilai koefisien determenasi sebesar $18 \%$. Nilai koefisien korelasi yang diperoleh dibandingkan dengan nilai t-tabel $=0,288$ dengan sample data 48, taraf signifikan $5 \%$. Terlihat bahwa nilai t-hitung lebih besar ttabel atau 0,424 >0,288, maka dapat dinyatakan terdapat hubungan yang positif dan signifikan antara disiplin kerja dengan efektivitas penerapan sistem manajemen mutu pada Universitas Budi Luhur. Hubungan disiplin kerja dengan efektivitas penerapan sistem manajemen mutu dapat diketahui melalui nilai koefisien determinasi $\mathrm{r}^{2}=(0,424)^{2}=0,180$. Jadi varian yang terjadi pada disiplin kerja sebesar $18 \%$ dapat dijelaskan melalui varian yang terjadi pada efektivitas penerapan sistem manajemen mutu, sedangkan sisanya sebesar $82 \%$ disebabkan oleh faktor lain. Model persamaan regresi linier sederhana yang diperoleh $\mathrm{y}=44.761+0,407 \mathrm{X}_{2}$.

Analisis korelasi berganda terhadap variabel motivasi dan disiplin kerja karyawan dengan efektivitas penerapan sistem manajemen mutu diperoleh hasil nilai koefisien korelasi berganda positif sebesar 0,524 (R-hitung). Nilai koefisien korelasi berganda yang diperoleh dengan sample data 48 dengan taraf signifikansi 5\%. Dengan demikian dapat diambil kesimpulan bahwa secara bersam-sama terdapat hubungan yang positif dan signifikan antara motivasi dan disiplin kerja dengan efektivitas penerapan sistem manajemen mutu. Hubungan motivasi dan disiplin kerja terhadap efektivitas penerapan sistem manajemen mutu dapat diketahui malalui nilai koefisien determinasi $\mathrm{R}^{2}=(0,524)^{2}=27,5 \%$. Jadi varian yang terjadi pada motivasi dan disiplin kerja sebesar $27,5 \%$ dapat dijelaskan melalui varian yang terjadi pada efektivitas penerapan sistem manajemen mutu, sedangkan sisanya $72,5 \%$ disebabkan oleh faktor lain.

Model persamaan regresi linier berganda yang diperoleh $\mathrm{Y}=29,997+$ $0,325 \mathrm{X}_{1}+0,264 \mathrm{X}_{2}$. Dari persamaan tersebut disimpulkan, bila kenaikkan 0,325 motivasi dan 0,264 disiplin kerja secara bersama-sama akan diikuti kenakkan 1 (satu) unit efektivitas penerapan sistem manajemen mutu. Uji Anova diperoleh nilai $\mathrm{F}$ hitung lebih besar $\mathrm{F}$ tabel $(8,522>3,21)$. Dengan mengambil taraf signifikansi $5 \%$, maka Ho ditolak artinya terdapat hubungan linier secara bersama-sama antara motivasi dan disiplin kerja dengan efektivitas penerapan sistem manajemen mutu. Sementara itu, dari hasil pendapat responden mengenai motivasi kerja dengan nilai mean 76,41 , disiplin kerja dengan nilai mean 70,27 dan efektivitas penerapan sisitem manajemen mutu nilai 
meannya sebesar 73,35, secara keseluruhan nilainya cukup tinggi.

\section{KESIMPULAN DAN SARAN}

Penelitian ini bertujuan untuk melihat hubungan dan pengaruh antara variabel motivasi kerja, disiplin kerja dan efektivitas penerapan sistem manajemen mutu berbasis ISO di Universitas Budi Luhur. Hasil penelitian menunjukkan bahwa terdapat hubungan yang positif antara motivasi kerja dengan efektivitas penerapan sistem manajemen mutu. Namun demikian pengaruh motivasi kerja terhadap efektivitas penerapan SMM ternyata hanya sebesar $21,3 \%$.

Demikian juga dengan hubungan antara variabel disiplin kerja dengan variabel efektivitas penerapan SMM. Keduanya memiliki hubungan yang positif namun tingkat pengaruhnya relatif kecil, yaitu sebesar $18 \%$. Selanjutnya penelitian ini juga melihat hubungan antara motivasi kerja dan disiplin kerja secara bersama-sama, terhadap efektivitas penerapan SMM. Pengaruh variabel independen secara simultan terhadap variabel dependen (efektivitas penerapan SMM) adalah sebesar 27,5\%. Dengan demikian, terdapat variabel lain di luar penelitian ini yang mempengaruhi efektivitas penerapan SMM sebesar 72,5\%.

Pada penelitian selanjutnya, perlu dilihat variabel-variabel atau faktor lain yang mempengaruhi kinerja dan mutu perguruan tinggi. Beberapa faktor yang mungkin dapat diteliti adalah penggunaan teknologi informasi, tingkat kesejahteraan dan budaya organisasi. Hasil penelitian lainnya (Tulodo \& Solichin, 2019), menunjukkan bahwa penerapan teknologi dapat meningkatkan kepuasan pengguna atau pelanggan di suatu perusahaan. Hal tersebut dapat diteliti pada kegiatan penelitian selanjutnya.

\section{DAFTAR PUSTAKA}

Agustina, H., Jaya, M., \& Pungan, Y. (2019). Pengaruh Karakteristik Individu, Komunikasi Efektif dan Kepuasan Kerja Terhadap Kinerja Karyawan (Studi pada PT Tambang Batubara Bukit Asam. ATTADBIR: Jurnal Ilmiah Manajemen, 3(1), 33-40.

Gujarati, D. N. (2004). Basic Econometrics. New York (4 ed.). https://doi.org/10.1126/science.1186874 Mulyadi, H., \& Marliana, N. (2010). Pengaruh Motivasi dan Disiplin Kerja Karyawan Terhadap Kinerja Karyawan pada Departemen Weaving PT. Adetex Cabang Banjaran Kab. Bandung. Strategic: Jurnal Pendidikan Manajemen Bisnis, 9(17), 51-75.

Sekaran, U. (2011). Metodologi Penelitian untuk Bisnis (Edisi 4). Jakarta: Salemba Empat.

South, C. Y. W. (2013). Pengaruh Motivasi dan Disiplin Kerja Pegawai dalam Peningkatan Kinerja Pegawai di Kantor Kelurahan Paniki I Kecamatan Mapanget Kota Manado. Jurnal Governance, 5(1), 1-10.

Sugiyono. (2012). Metode Penelitian Kuantitatif Kualitatif dan $R \& D$. Bandung: Alfabeta.

Sujarweni, V. W. (2012). SPSS untuk Paramedis (1 ed.). Gava Media.

Tampubolon, D. P. (2001). Perguruan Tinggi Bermutu: Paradigma Baru Manajemen Pendidikan Tinggi Menghadapi Tantangan Abad ke-21. Jakarta: Gramedia Pustaka Utama.

Tulodo, B. A. R., \& Solichin, A. (2019). Analisis Pengaruh Kualitas Sistem, Kualitas Informasi dan Perceived Usefulness Terhadap Kepuasan Pengguna Aplikasi CARE dalam Upaya Peningkatan Kinerja Karyawan. JRMSI 
- Jurnal Riset Manajemen Sains Indonesia, 10(1), 25-43.

Universitas Budi Luhur. (2011). Peraturan Kepegawaian 2011 Universitas Budi Luhur. Universitas Budi Luhur.

Utama, N. P., Mansur, M., \& Slamet, A. R. (2017). Pengaruh Motivasi Kerja dan Disiplin Kerja Terhadap Efektivitas Kerja Pegawai (Studi Kasus Pada
Yayasan Sunan Kalijogo JabungMalang). Jurnal Riset Manajemen, 6(7), 45-58.

Yunimas, A., \& Putro, A. (2016). Analisis Disiplin dan Motivasi terhadap Kinerja Karyawan pada CV Putra Luhur Blitar. Jurnal Penelitian Manajemen Terapan (PENATARAN), 1(1), 50-64. 